\title{
Training Needs Measure for Health Care of the LGBT+ Public
}

\author{
Willian Roger Dullius ${ }^{1}$ \\ Lara Barros Martins ${ }^{1}$
}

\begin{abstract}
Inadequate and ineffective care provided by health professionals to the LGBT+ public can cause countless damages to those who demand care. An alternative to improve the service provided is to promote training actions for professionals that should be initiated by the Training Needs Analysis (TNA). This study aimed at building and validating, theoretically and statistically, a TNA instrument for health professionals related to humanized care for LGBT+ individuals for the Brazilian context. The data collection was done in two stages, in person and virtually, and had 449 professionals who responded to the TNA instrument built. The data was analyzed by means of content analysis, exploratory factors and internal consistency. The scale presented a uni-factorial structure with evidence of validity and reliability, and can be used as a diagnostic tool to verify the gaps in the competence of health professionals in the care of LGBT+ people.
\end{abstract}

Keywords: health professionals, personnel training, factor analysis, minority groups

\section{Medida de Necessidades de Treinamento para Atenção em Saúde ao Público LGBT+}

Resumo: A assistência inadequada e ineficaz proporcionada por profissionais de saúde ao público LGBT+ pode causar inúmeros danos àqueles que demandam cuidados. Uma alternativa para melhorar o atendimento prestado é promover ações de capacitação aos profissionais que devem ser iniciadas pela Análise de Necessidades de Treinamento (ANT). O presente estudo teve como objetivo construir e validar, teórica e estatisticamente, um instrumento de ANT destinado aos profissionais de saúde relacionado ao atendimento humanizado ao indivíduo LGBT+ para o contexto brasileiro. A coleta de dados foi feita em duas etapas, presencial e virtualmente, e contou com 449 profissionais que responderam ao instrumento de ANT construído. Os dados foram analisados mediante análises de conteúdo, fatoriais exploratórias e de consistência interna. A escala apresentou uma estrutura unifatorial com evidências de validade e confiabilidade, podendo ser utilizada como ferramenta de diagnóstico para verificar as lacunas de competências dos profissionais de saúde quanto ao atendimento às pessoas LGBT+.

Palavras-chave: profissionais da saúde, treinamento de pessoal, análise fatorial, grupos minoritários

\section{Medida de Necesidades de Entrenamiento para la Atención en Salud al público LGBT+}

\begin{abstract}
Resumen: La atención inadecuada e ineficaz que brindan los profesionales de la salud al público LGBT+ puede causar numerosos daños a quienes la necesitan. Una alternativa para mejorar el servicio prestado es promover la capacitación de profesionales, que debe ser iniciada por el Análisis de Necesidades de Entrenamiento (ANE). El estudio describe los procedimientos de construcción y validación, teórica y estadística, de un instrumento de ANE destinado a los profesionales de la salud que trabajan con población LGBT+. La recogida de datos fue realizada en dos etapas, presencial y virtualmente, y contó con 449 profesionales que respondieron al instrumento de ANE construido. Los datos fueron analizados mediante análisis de contenido, factoriales exploratorios y de consistencia interna. La escala presentó una estructura unifactorial con evidencias de validez y fiabilidad, pudiendo ser utilizada como herramienta de diagnóstico para verificar las deficiencias de competencias de los profesionales de la salud cuanto al atendimiento a las personas $\mathrm{LGBT}+$.
\end{abstract}

Palavras clave: profesionales de la salud, entrenador personal, análisis factorial, grupos minoritarios

${ }^{1} I M E D$, Passo Fundo-RS, Brazil

Support: Article derived from the master's thesis of the first author under the supervision of the second, defended in 2018, in the Stricto Sensu Postgraduate Program in Psychology at IMED. The study did not receive financial support.

Correspondence address: Willian Roger Dullius. IMED. Escola de Saúde, Psicologia. Rua Senador Pinheiro, 304, Passo Fundo-RS, Brazil. CEP 99.070-220. E-mail: rogerdullius@gmail.com
Currently there is a high demand for mental health care by non-heteronormative individuals (Müller, 2013). Reports from LGBT + individuals (Lesbian, Gay, Bisexual, Transvestite and the + sign for the other gender names: Transgender, Queer and Intersex) indicate that they perceive a difference in the way they are cared for by health professionals, who provide assistance in a negative manner due to their sexual 
orientation, for example, incorrectly use their pronoun and social name, have disrespectful attitudes, do not consider the patient's opinion, and decisions are made exclusively by the professionals themselves (Alpert, Cichoskikelly, \& Fox, 2017; Costa et al., 2018; Dowshen et al., 2016; Müller, 2013). From the point of view of the LGBT+ public, when seeking health services, they perceive: unpreparedness of professionals to deal with the gay public; use of jokes and debauches; impact on the eyes; amazement at the practices among lesbians; discriminatory gynecological care; lack of professional training; lack of attention to the LGBT+ population, among others (Carvalho \& Philippi, 2013).

Such failures are related to the educational system performed in the academies, which fail to teach future professionals in the care of sexual minorities, and there is no continued education on the subject (Beagan, Fredericks, \& Bryson, 2015; Müller, 2013; Paradiso \& Lally, 2018). Consequently, there is insecurity in providing care due to a fragmented teaching and support base (Paradiso \& Lally, 2018). In this respect, the literature suggests that the curriculum base should be better elaborated and more research in the medical area related to this subject be developed (Zelin et al., 2018).

Therefore, curricula should include the mastery of clinical skills, knowledge, and attitudes that result in the reduction of the health care gap for the $\mathrm{LGBT}+$ public, since there are indications of failures in the education of doctors, nurses and other health professionals who should equip them to promote the health care of these individuals (Dubin et al., 2018; Talan, Drake, Glick, Claiborn, \& Seal, 2017).

One way to minimize such embarrassing situations is by offering training for health professionals to improve care for LGBT+ patients. Thus, this situation calls attention to the need for qualification on sexual minorities and development of skills in assistance in this area by professionals, since the mental health of this population is weakened due to the numerous negative factors they face daily by the lgbtphobia present in society (Paradiso \& Lally, 2018).

When looking at (continuing) sexual and gender minority education, health professionals often have a considerable gap in specific skills to provide care to them efficiently, due mainly to the lack of training in this regard. In order to account for the needs of all publics in the health sector, it is a priority to develop researches that glimpse the opinion and health of these people so that there is continuous training of these professionals, in those essential competencies not dominated by them, so that there is quality and effectiveness in the assistance performance (Alpert et al., 2017; Carabez et al., 2015; Moe \& Sparkman, 2015; Müller, 2013). Thus, the acquisition and consolidation of skills by health professionals, through training and continuing education throughout their careers, guides a humanized and quality assistance to those in need of health care.

Training needs analysis (TNA) is one of the steps that constitute the Training, Development and Education (TD\&E) system of people, which has the role of evaluating the existing or deficient skills in a population that can be trained (Meneses, Zerbini, \& Silva, 2010). TNA provides verification of information regarding the technical and/or behavioral skills that need to be transmitted to people, in addition to differentiating each individual in their degree of knowledge and need to receive training in a given topic. Such analysis is carried out using an indicator, the GPI - General Priority Index, which identifies training priorities, that is, those activities or behaviors that are important for the good performance of the function at work, but little dominated by the individual (Borges-Andrade \& Lima, 1983).

The need for training, therefore, refers to competencies (set of knowledge, skills and attitudes - KSAs) that are fundamental to the position, but which have not yet been developed, consolidated or need to be recycled to ensure competent performance. This includes, beyond the skills, the motivation and conditions to perform the activities at work. Performance problems caused by lack of motivation or conditions do not configure themselves as training needs, and need to be solved through other strategies and interventions (Meneses \& Zerbini, 2009).

By systematically identifying divergences between actual performances, manifested by individuals, and those required by the work unit or organization, decision making on the contents and skills important for a good performance of the daily occupational role at work is optimized. Therefore, TNA aims to assess performance problems caused exclusively by competence gaps, and then propose learning solutions, via educational actions (Meneses \& Zerbini, 2009).

Some initiatives to offer short training to health professionals, focusing on reducing their negative attitudes towards sexual and gender minorities, have been carried out in the field of policies and health care in AIDS cases (Poteat et al., 2017). In addition, international literature provides a Lesbian, Gay, Bisexual, and Transgender Development of Clinical Skills Scale - LGBT-DOCSS (Bidell, 2017), which evaluates clinical skills, attitudes and basic knowledge of health professionals in the care of LGBT+ people, and can guide introductory training sessions. Despite its good psychometric characteristics, LGBT-DOCSS is not suitable for TNA of any health professionals, because it is not based on competencies, but on perceptions and attitudes.

In Brazil, the National Integral Lesbian, Gay, Bisexual, Transvestite and Transgender Health Policy (Ministry of Health, 2013) represents an effort to meet the demands of this vulnerable public, seeking to avoid institutional discrimination and prejudice in public health services. It serves as a guide to professional practice and provides guidance on the needs and specificities of gender, orientation and affective, and sexual practices of LGBT+ people. However, there is not yet a national or international competence benchmark that can contribute to the performance of health professionals, as well as guide professional training and qualification in the area of sexual and gender minorities.

The combination of restricted teaching during graduation, the scarcity of continuous education in daily life, the lack of regulations or guidelines that prescribe the professional skills required to attend to the LGBT+ population, end up 
contributing to inadequate means of support being provided to the individual who requires help and health care. Thus, an instrument capable of advising and better planning educational actions directed at and pertinent to health professionals regarding the care of the LGBT+ public, which can be a useful diagnostic and intervention tool for resolving inappropriate assistance and solving momentary and longterm problems in the performance of professionals is needed.

According to the data presented, the existing difficulties arise not only in a specific professional category, but in several professional categories in the health area. The methodology of applying a TNA tool is able to identify the importance of each competence for each professional who responds, which makes possible the creation of a generic tool for all professional categories at the same time.

In this sense, the present study aimed at building and validating, theoretically and statistically, a TNA instrument for health professionals related to humanized care for LGBT+ individuals for the Brazilian context. The instrument makes it possible to identify the deficient skills that need to be trained and analyze those necessary for the good performance of health professionals' care routines, regardless of their area or context of operation, to the LGBT+ public in their daily work, encompassing questions about the individual, the professional, work colleagues, the health unit, and the community.

\section{Method}

\section{Participants}

In the first phase of the survey, of a qualitative nature for mapping the competencies required to assist the LGBT+ public, the sample was composed of 319 health professionals, among whom $46.4 \%$ were psychologists, $21 \%$ nurses, $7.2 \%$ doctors, $6.9 \%$ social workers, and $18.5 \%$ other health professionals. The predominant profile was women $(82.8 \%)$, heterosexual $(81.8 \%)$, with 26 to 35 years of age (35.1\%).

In the second phase, which consisted in applying the validated TNA instrument, in terms of its content to 449 health professionals: psychologists $(41.9 \%)$, nurses (23.8\%), nursing technicians (12.2\%), doctors (5.3\%), and other professional categories (16.6\%); acted as freelancers $(33.2 \%)$, in the hospital area $(23.2 \%)$, in public health $(22.0 \%)$, or both $(9.8 \%)$, in universities $(5.6 \%)$ and in the third sector $(4.0 \%)$. The predominant profile was women $(83.1 \%)$, heterosexual $(74.2 \%)$, aged 26 to 35 years (34.5\%), with specialization $(43.7 \%), 10$ years or more of profession $(33.9 \%)$, and professional performance in the south (38.5\%) and southeast (32.5\%) regions of Brazil.

\section{Instrument}

The instrument Measuring Training Needs for Health Care for the LGBT+ Public, produced from the aforementioned KSAs survey process, underwent theoretical validation, which took place from semantic validation and validation by judges described below. The sample of the semantic validation was composed by seven health professionals who were attending post-graduation courses (Master in Psychology), with different backgrounds. The subsequent stage, the validation by judges, was composed of five participants (four $\mathrm{PhDs}$ and one $\mathrm{PhD}$ student), from the Medicine and Psychology area.

\section{Procedure}

Data collection. Divided into two stages: the first, aimed at building the actual items of the TNA instrument, and the second, validating it theoretically and statistically.

The first stage of the study, for the construction of the instrument, was carried out entirely via Internet. A Google Forms link was made available for health professionals to access, which contained a form with open questions to map out which skills were required to assist the LGBT+ individual, according to their area of activity and professional practice. The link was made available along with a brief invitation explaining the purpose of the research, via e-mail and social networks for dissemination and sharing by other health professionals, using the snowball method. Based on the skills described in the first stage, it was possible to list 41 skills needed by health professionals in attending the LGBT+ population. This list was submitted to theoretical validation and then a measurement instrument of 41 items was created.

In the second stage, after the theoretical validation, the instrument was applied in person to health professionals from the public and hospital networks of two cities in the northern region of the state of Rio Grande do Sul; and via internet, available for open access by health professionals through a link to the Google Forms form, disclosed again by email and social networks. In this link there was a form requesting the socio-demographic and functional data of the sample of participants, as well as the TNA instrument, so that the professionals could respond, according to their daily professional activities, their judgments regarding the importance and mastery of the skills described.

Data analysis. After the collection, the data were analyzed, in terms of their contents, through the NVivo Program version 12.0 , for the codification of the KSAs described by the participants; after the categorization of the data, they were grouped into 19 pre-categories. After a more in-depth analysis of the initial categories raised, grouping the items that resembled in content, a version with 51 items was proposed, which went through semantic validation (checking whether items, categories and instructions for filling the instrument are intelligible to the target audience) and validation by judges (checking the suitability of the behavioral representation of the latent attribute(s) by experts in the area of the construction under analysis) (Pasquali, 2010).

At the end of the second stage of data collection, statistical analyses of the data were performed in the SPSS (Statistical Package for the Social Science) version 23.0 program, according to the guidelines of Field (2009), Hair, Black, 
Babin, Anderson and Tatham (2009), Pasquali (2005) and Tabachnick and Fidell (2013): (a) descriptive (mean, standard deviation, mode, minimum and maximum, concentration of responses) and exploratory analyses of the data (data entry, presence of extreme cases, frequency distribution of variables and sample size); (b) exploratory factorial analyses - EFA (principal components and principal axis factoring methods) and of internal consistency (Cronbach's Alpha) for the verification of evidences of validity and reliability of the constructed measurement instrument (TNA); (c) calculation of the General Priority Index (GPI = Importance $\mathrm{x}$ Inverted Domain) for each competence listed in the TNA instrument the GPI can vary between 1 and 25 , being that the values above 16 indicate training priorities (Borges-Andrade \& Lima, 1983).

\section{Ethical Considerations}

Regarding ethical issues, the project was submitted to and approved by the Research Ethics Committee of the Southern College - IMED (CAAE No. 69116917.6.0000.5319). The requirements for conducting research with human beings, such as the confidentiality of both participants and the information obtained, were met. It was also safeguarded that the participants, by signing the Free and Informed Consent Term, could know the purposes of the research and participate in a voluntary manner.

\section{Results}

\section{Theoretical Validation}

In the process of semantic validation, the observations and considerations of health professionals who were attending graduate school were systematized to allow their analysis. In the instructions for filling out the instrument, it was suggested and accepted the exclusion in brackets of the meaning of the acronym LGBT+ (Lesbian, Gay, Bisexual, Transvestite, Transgender) and, regarding the items of the instrument, small grammatical and verbal agreement adjustments were made in items 8,12 and 26 .

In the validation by judges, the term "client" was changed to "patient" throughout the instrument, since medical terminology generally uses the term "patient" to refer to the individual although there are differences in the term "client"/"patient" in the literature, the term "patient" was chosen, as suggested by one of the judges; the term LGBT+ was removed in brackets, since although it tried to cover all the designations, it ended up excluding some. Therefore, it is understood that the acronym is already known to the population, which includes all individuals who do not call themselves heterosexual; other small grammatical changes have been made in the instructions of the instrument for its better understanding.

Regarding the changes in the items of the instrument, in item 1 the word "thematic" was replaced by "theme"; in item 20 the word "action" was changed to "attention"; in item 26 the word "unit" was removed, in order to cover, besides the health unit, other daily contexts; in item 4 the words "terms" and "sexual and gender diversity" were added; in item 28 "by health professionals" was included; in item 44 "with the patient" was added, because according to the judge, planning is not carried out only with couples, but with all patients; in items 19, 22, 23, 35 the term "sexual diversity" was added to maintain the standardization in the instrument "sexual and gender diversity"; item 5 was rewritten, since it was considered confusing, having been added examples of professional councils; in item 6 the action verb of "apply" was modified to "perform"; items 8,14, 16, 17, 24, 25, 46, 47, 48 and 50 were excluded, since they were already contained or present great similarity of content with other items of the instrument, according to the experts' appreciation.

As for specific terms such as "hebiatry", "childcare" and "heteronormative", among others, it was suggested by some judges that there should be an explanation for each term in the sentences; however, it was considered that these terminologies are taught during graduation to professionals and the item would be too long; furthermore, as it is a TNA instrument, the lack of knowledge of the term by the professional would demonstrate the need for training in this regard.

\section{Statistical Validation}

The responses of the 484 participants to the 41 items of the TNA instrument presented 35 univariate outliers that were excluded, totaling 449 valid cases. These cases were excluded because, although EFA is robust to the presence of outliers, they could interfere in the calculation of the GPI further on. Missing values were identified between $11(2.4 \%)$ and $23(5.1 \%)$ cases in the whole instrument, randomly distributed, and it was not necessary to estimate values to replace them, because the percentage did not exceed the 5\% criterion established.

Anticipating the analysis of principal components, to perform the analysis of the covariance matrix in terms of factorability, the size of the correlations and the adequacy of the sample were analyzed, as well as some desirable characteristics described by Pasquali (2005): there are around 11 cases for each item of the instrument; the presence of linear relations between variables was identified; in more than $50 \%$ of the cases there is significant correlation between the items of the instrument and correlation values higher than 0.30; no pairs of highly correlated items were identified ( $r>0.80)$, evidencing that there is no multicollinearity. As for the Kaiser-Meyer-Olkin (KMO) test, a value of 0.95 was obtained, considered an excellent sample adequacy index and the Bartlett sphericity test were significant.

The initial extraction of factors was done through analysis of the principal components (PC), following the conventional criteria of analysis of the eigenvalues and their distribution; the statistical criteria of Horn's parallel analysis; and the criteria of importance of the factor. The interpretability and consistency criteria were made after the rotation of the factors.

The PC, with pairwise treatment for the missing cases, suggests an empirical structure with six components that 
together explain $63.77 \%$ of the total variance of the participants' responses to the questionnaire items. Such analysis followed the criterion of eigenvalues greater than or equal to one. Regarding the importance of the factor, Harman's criterion (Pasquali, 2005) indicates that each component should explain at least $3 \%$ of the total variance. Thus, six factors at most could be extracted. The scree plot and Horn's parallel analysis confirmed the existence of, at most, four components.

As in the analysis of the eigenvalues and the variance explained, an indication of the existence of six components was obtained, against the four indicated by the parallel analysis and scree plot, solutions were tested with four and six factors, at first. However, it was found that the comparison of the size of the factor 1's eigenvalues (and its percentage of variance explained) is much larger than the others, which indicates that there is a factor that stands out from the others. Thus, the final extraction of the factors was performed with solutions with 1, 4 and 6 factors.

The final extraction of the factors of the TNA instrument was performed by means of the principal axis factoring (PAF), with the oblique rotation method (obimin direct) and pairwise treatment for omitted cases. Only items with similar semantic content and factor loads greater than or equal to 0.40 were included in the scale, as they are considered stable and good representatives of the factor. In PAF with six and four factors, several items shared variance in more than one factor; in PAF with only one factor, 40 items had factor load above 0.40 , and only one item had factor load equal to 0.39 , a value slightly below the established criterion. In the solution with four and six factors, respectively, six and 14 items presented factor load below this value. Thus, regardless of the factorial solution chosen, the stability of the items remains similar. Analyzing the content of the items, it was observed a better adequacy in the extraction of only one factor, being that 20 items of shared loads that remain in the first factor, in fact, would belong to the other five factors, if the criterion of content of the items was considered. Therefore, we opted for the unifactorial structure (eigenvalue of Factor $1=17.06$ ), which explains $41.61 \%$ of the total variance of the responses to the items of the instrument.

Items 2 "Ask the patient about his or her sexual orientation" and 8 "Show respect for topics the patient prefers not to talk about" did not remain in the instrument's single-factor empirical structure. It is worth noting that in solutions with 4 and 6 factors, item 8 never remained in the structure, and item 2, although it remained, contained the lowest factor load compared to the others. Therefore, the final version of the TNA instrument has 39 items and an excellent internal consistency index $(\alpha=0.96)$ - the other psychometric characteristics can be consulted in Table 1.

Table 1

Empirical structure of the TNA Instrument and descriptive results of the GPI evaluated in the sample of health professionals

\begin{tabular}{|c|c|c|c|c|c|c|c|}
\hline \multirow[b]{2}{*}{ Items } & \multirow{2}{*}{$\begin{array}{c}\text { Psychometric } \\
\text { Factorial } \\
\text { Loads }\end{array}$} & \multirow{2}{*}{$\begin{array}{c}\text { Characteristics } \\
h^{2} \\
\end{array}$} & \multicolumn{2}{|c|}{ Descriptive Craps } & \multicolumn{3}{|c|}{ Concentration of Answers $\% *$} \\
\hline & & & $X$ & $S D$ & 1 to 5 & 6 to 15 & to 25 \\
\hline 1.Use the patient's preferred pronoun. & 0.444 & 0.197 & 7.98 & 3.72 & 48.6 & 48.9 & 2.5 \\
\hline $\begin{array}{l}\text { 2.Ask the patient about his or her sexual } \\
\text { orientation. }\end{array}$ & & 0.154 & 8.08 & 4.28 & 41.8 & 54.6 & 3.7 \\
\hline $\begin{array}{l}\text { 3.Use the social name when addressing the } \\
\text { patient. }\end{array}$ & 0.465 & 0.216 & 7.56 & 4.97 & 56.8 & 39.7 & 3.4 \\
\hline $\begin{array}{l}\text { 4.Approach the topic of sexuality with the } \\
\text { patient. }\end{array}$ & 0.523 & 0.274 & 9.09 & 4.22 & 33.2 & 62.1 & 4.6 \\
\hline $\begin{array}{l}\text { 5.Addressing the issue of sexually transmitted } \\
\text { infections with the patient. }\end{array}$ & 0.557 & 0.310 & 9.18 & 4.45 & 34.4 & 59.3 & 6.4 \\
\hline $\begin{array}{l}\text { 6.To adapt the anamnesis to the singularities } \\
\text { of the patient. }\end{array}$ & 0.504 & 0.254 & 9.36 & 4.25 & 33.9 & 61 & 5.1 \\
\hline $\begin{array}{l}\text { 7.Demonstrate interest in learning with the } \\
\text { patient subjects that I do not master. }\end{array}$ & 0.401 & 0.161 & 8.19 & 3.92 & 46.5 & 49.8 & 3.7 \\
\hline $\begin{array}{l}\text { 8.Demonstrate respect for topics that the } \\
\text { patient prefers not to talk about. }\end{array}$ & & 0.068 & 7.32 & 3.10 & 54.1 & 44.7 & 1.1 \\
\hline
\end{tabular}


Continuation...

Table 1

Empirical structure of the TNA Instrument and descriptive results of the GPI evaluated in the sample of health professionals

\begin{tabular}{|c|c|c|c|c|c|c|c|}
\hline \multirow[b]{2}{*}{ Items } & \multirow{2}{*}{$\begin{array}{c}\text { Psychometric } \\
\text { Factorial } \\
\text { Loads }\end{array}$} & \multirow{2}{*}{$\begin{array}{c}\text { Characteristics } \\
h^{2} \\
\end{array}$} & \multicolumn{2}{|c|}{ Descriptive Craps } & \multicolumn{3}{|c|}{ Concentration of Answers \%* } \\
\hline & & & $X$ & $S D$ & 1 to 5 & 6 to 15 & to 25 \\
\hline $\begin{array}{l}\text { 9.Discuss with the patient the legal regulations } \\
\text { regarding their assistance in the health system. }\end{array}$ & 0.637 & 0.405 & 11.77 & 5.36 & 18.5 & 65.4 & 16 \\
\hline $\begin{array}{l}\text { 10.Discuss prejudice against sexual and } \\
\text { gender diversity internalized in the patient. }\end{array}$ & 0.650 & 0.423 & 9.88 & 4.87 & 31.4 & 59.8 & 8.7 \\
\hline $\begin{array}{l}\text { 11. To reinforce the importance of patient } \\
\text { participation in the social context. }\end{array}$ & 0.665 & 0.442 & 9.08 & 4.34 & 36.7 & 57.5 & 5.7 \\
\hline $\begin{array}{l}\text { 12.Be alert to influences of religious beliefs } \\
\text { that may interfere with patient care. }\end{array}$ & 0.471 & 0.222 & 8.58 & 3.82 & 38.8 & 58.2 & 3.0 \\
\hline $\begin{array}{l}\text { 13.Explain the specifics of hormone therapy } \\
\text { to the patient. }\end{array}$ & 0.518 & 0.269 & 13.96 & 6.36 & 14.4 & 54.7 & 31.1 \\
\hline $\begin{array}{l}\text { 14. Encourage the patient to participate } \\
\text { in daily activities of the health unit (e.g. } \\
\text { operating groups, health care task forces, } \\
\text { conversation wheels). }\end{array}$ & 0.639 & 0.408 & 9.60 & 4.75 & 33 & 58.4 & 8.7 \\
\hline $\begin{array}{l}\text { 15. Guide the transsexual patient in breast } \\
\text { and genital care. }\end{array}$ & 0.633 & 0.401 & 12.64 & 6.21 & 20.1 & 56.7 & 23.2 \\
\hline $\begin{array}{l}\text { 16.Perform the hebiatry of transsexual } \\
\text { adolescents. }\end{array}$ & 0.437 & 0.191 & 14.85 & 6.58 & 12.8 & 49.5 & 37.7 \\
\hline $\begin{array}{l}\text { 17. Carry out the child care of transsexual } \\
\text { children. }\end{array}$ & 0.448 & 0.200 & 14.98 & 6.89 & 15.4 & 46.6 & 37.8 \\
\hline 18.Carry out family planning with the patient. & 0.631 & 0.398 & 11.21 & 6.04 & 29.4 & 53.2 & 17.5 \\
\hline $\begin{array}{l}\text { 19.Identify the barriers that patients face to } \\
\text { obtain health care. }\end{array}$ & 0.749 & 0.561 & 10.53 & 5.11 & 29 & 59.7 & 11.3 \\
\hline $\begin{array}{l}\text { 20.Identify the organic specificities within } \\
\text { sexual and gender diversity. }\end{array}$ & 0.719 & 0.518 & 12.44 & 5.76 & 18.3 & 60.5 & 21.2 \\
\hline $\begin{array}{l}\text { 21. Rewrite clinical protocols of care to meet } \\
\text { the reality of the patient. }\end{array}$ & 0.674 & 0.455 & 12.24 & 5.84 & 18.8 & 61 & 20.2 \\
\hline $\begin{array}{l}\text { 22.Adapt the terms of the medical record } \\
\text { according to sexual and gender diversity. }\end{array}$ & 0.706 & 0.499 & 10.36 & 5.55 & 32.8 & 55.6 & 11.4 \\
\hline $\begin{array}{l}\text { 23.Carry out the actions set forth in the } \\
\text { National Policy for LGBT+ Integral Health. }\end{array}$ & 0.751 & 0.564 & 13.15 & 6.00 & 15.8 & 60.8 & 23.4 \\
\hline $\begin{array}{l}\text { 24.Identify bioethical principles related to } \\
\text { sexual diversity and gender. }\end{array}$ & 0.692 & 0.478 & 12.26 & 5.72 & 18.4 & 60.9 & 20.7 \\
\hline $\begin{array}{l}\text { 25.Identify psychological specificities within } \\
\text { sexual and gender diversity. }\end{array}$ & 0.702 & 0.493 & 11.25 & 5.48 & 24.8 & 60.5 & 14.7 \\
\hline $\begin{array}{l}\text { 26.Identify vulnerability to patient illness } \\
\text { due to discrimination in health spaces. }\end{array}$ & 0.772 & 0.596 & 10.21 & 5.08 & 32 & 57.9 & 10.3 \\
\hline $\begin{array}{l}\text { 27.Execute awareness campaigns about the } \\
\text { rights of LGBT+ people. }\end{array}$ & 0.769 & 0.591 & 11.81 & 5.97 & 24.9 & 56.6 & 18.3 \\
\hline
\end{tabular}


Continuation...

Table 1

Empirical structure of the TNA Instrument and descriptive results of the GPI evaluated in the sample of health professionals

\begin{tabular}{|c|c|c|c|c|c|c|c|}
\hline \multirow[b]{2}{*}{ Items } & \multirow{2}{*}{$\begin{array}{c}\text { Psychometric } \\
\text { Factorial } \\
\text { Loads }\end{array}$} & \multirow{2}{*}{$\begin{array}{c}\text { Characteristics } \\
h^{2}\end{array}$} & \multicolumn{2}{|c|}{ Descriptive Craps } & \multicolumn{3}{|c|}{ Concentration of Answers \%* } \\
\hline & & & $X$ & $S D$ & 1 to 5 & 6 to 15 & to 25 \\
\hline $\begin{array}{l}\text { 28.Seek help from other professionals if you } \\
\text { have doubts about patient care. }\end{array}$ & 0.607 & 0.369 & 8.28 & 4.27 & 50.2 & 45.2 & 4.7 \\
\hline $\begin{array}{l}\text { 29.Share with colleagues positive experiences } \\
\text { of LGBT+ public care practices. }\end{array}$ & 0.741 & 0.549 & 9.54 & 5.11 & 39.5 & 50.4 & 10.2 \\
\hline $\begin{array}{l}\text { 30.Correct discriminatory information about } \\
\text { the patient in the multi-professional team. }\end{array}$ & 0.668 & 0.447 & 8.84 & 4.33 & 41.3 & 53.6 & 5 \\
\hline $\begin{array}{l}\text { 31.Discuss legal regulations regarding patient } \\
\text { care with other professionals. }\end{array}$ & 0.683 & 0.467 & 12.97 & 5.81 & 15.5 & 61.3 & 23.2 \\
\hline $\begin{array}{l}\text { 32.Discuss with colleagues about forms of } \\
\text { care with the patient. }\end{array}$ & 0.730 & 0.533 & 9.25 & 4.54 & 37.6 & 55.1 & 7.3 \\
\hline $\begin{array}{l}\text { 33.Discuss prejudice against sexual and gender } \\
\text { diversity in the multi-professional team. }\end{array}$ & 0.726 & 0.527 & 9.42 & 4.71 & 38.6 & 53.6 & 7.8 \\
\hline $\begin{array}{l}\text { 34.Be alert to forms of discrimination against } \\
\text { patients practiced by other professionals. }\end{array}$ & 0.638 & 0.408 & 8.63 & 4.15 & 43.6 & 51.9 & 4.4 \\
\hline $\begin{array}{l}\text { 35. Be alert to the use of heteronormative } \\
\text { patterns by professionals. }\end{array}$ & 0.674 & 0.454 & 9.81 & 4.96 & 35.5 & 55.4 & 9.1 \\
\hline $\begin{array}{l}\text { 36. Encourage colleagues to participate in } \\
\text { patient care training. }\end{array}$ & 0.648 & 0.421 & 9.19 & 4.41 & 39.1 & 55 & 5.9 \\
\hline $\begin{array}{l}\text { 37.Provide an inclusive environment for the } \\
\text { patient at the health care facility. }\end{array}$ & 0.665 & 0.443 & 9.23 & 4.65 & 38.9 & 54.5 & 6.5 \\
\hline $\begin{array}{l}\text { 38.Demand the construction of LGBT+ } \\
\text { population health policies from professional } \\
\text { councils (CRP, CRM, Coren, etc.) }\end{array}$ & 0.715 & 0.512 & 12.57 & 5.83 & 19.5 & 60.2 & 20.2 \\
\hline $\begin{array}{l}\text { 39.Discuss sexual and gender diversity with } \\
\text { the health unit's wider community. }\end{array}$ & 0.781 & 0.611 & 11.64 & 5.85 & 25.2 & 55.4 & 19.5 \\
\hline $\begin{array}{l}\text { 40.Listen to the demands from the LGBT+ } \\
\text { community. }\end{array}$ & 0.711 & 0.506 & 10.21 & 5.38 & 35.2 & 53 & 11.8 \\
\hline $\begin{array}{l}\text { 41.Invite members of the LGBT+ community } \\
\text { to discussions with the multidisciplinary team. }\end{array}$ & 0.720 & 0.519 & 11.19 & 5.90 & 30.5 & 51.9 & 17.6 \\
\hline
\end{tabular}

Note. TNA $=$ Training Needs Analysis; GPI $=$ General Priority Index; $\mathrm{h}^{2}=$ item communalities; $* 1$ to $5=1$ low training priority; 6 to $15=$ medium training priority; 16 to $25=$ high training priority.

\section{Analysis of General Priority}

Regarding the analysis of the General Priority Index (GPI), it can be seen that the group of health professionals that participated in the survey presented, in general, an intermediate training priority (means between 7.32 and 14.85; standard deviation between 3.10 and 6.89), no item presented high training priority, and only three items (GPI 3, GPI 8 and GPI 28) presented low training priority (see the descriptive results of the GPI evaluated by the
ANT instrument in Table 1). These items are related to the use of the corporate name when serving the individual, demonstrating respect for the individual and the issues that the person does not want to report, and about seeking support from co-workers when they do not have mastery of the issue addressed during customer service. Another point to be considered is the greater concentration of missing answers in the items dealing with the professional jargon "childcare" and "hebiatry", which may indicate the lack of knowledge of these professionals about the terms and their 
actions in assisting individuals of these age groups, that is, children and adolescents.

\section{Discussion}

The results revealed a unifatorial empirical structure for the TNA instrument, with theoretical and statistical meaning, according to the careful validations performed. The values of the internal consistency index (Cronbach's Alpha) and the factor loads show that the instrument presents reliability and evidence of validity. Therefore, the proposed instrument is configured as a diagnostic tool for health professionals and health system managers, such as hospitals and other care contexts, by providing a survey of the gaps in the skills of professionals in attending the LGBT+ public. The training needs assessment would subsidize the interventions according to the results obtained, proposing educational actions according to the identified training priority levels and with the participation of those professionals who should effectively develop or consolidate a set of skills not mastered, but important for the performance of their functions.

As the TNA instrument has many items in a single factor solution, one should consider increasing the value of $\alpha$, known to be inflated by the number of items. However, no redundancy or pairs of highly correlated items were identified, according to the multicollinearity analysis, which corroborates the structure found and the maintenance of the 39 items in the solution.

After the theoretical validation period, some health professionals sent complementary suggestions, such as: not using the term "patient", but "user or person"; instead of using the term "transsexual", replace it with "transsexual person"; regarding "family planning" it was suggested to modify it to "reproductive planning"; and, some physical education professionals claimed their participation as members of the multidisciplinary primary care health team. These suggestions should be taken into consideration in future applications of the instrument.

The health professionals who composed the sample designated, in general, a high importance for the items presented, as well as considered mastering the skills described. When checking the GPI, the concentrations of responses are located in the midpoints (at the limit for high training priority), which indicate medium training priority for this sample of professionals, and there are no gaps that should be immediately addressed through educational actions, but there are indications that there are skills that would merit attention, such as, for example, those that include addressing the issue of sexuality with the user; discussing with the user the legal regulations on health system assistance; rewriting protocols for LGBT+ users, with the inclusion of the National Integral LGBT + Health Policy, in addition to involving class councils in aiding humanized assistance.

However, the items obtained high standard deviation values (ranging from 3.10 to 6.89), which means that there is disagreement among the participants' responses regarding the analysis of importance or mastery of the skills evaluated, possibly due to the heterogeneity of the professional categories that composed the sample. There are competencies that fit more directly in the performance of certain professional categories and less in others, which may have led respondents to say that they are important, but do not dominate them although the instructions for completion clarify that each competence should be analyzed with focus on the function performed and not on its importance as a whole for health care. It would be interesting, for a next application of the measure, to obtain a sample uniformly distributed among the various professional categories, making it possible, by means of statistical analyses of comparison between groups, to verify if there are significant differences in the means obtained according to the perception of the gaps between the different health professionals. In this study, it was not possible to identify if there is a certain professional category that would need training, making it impossible to find results that would differentiate the professional categories from one another.

The items of the TNA instrument encompass competences in the cognitive, affective and psychomotor domains, with a predominance of those of a cognitive nature, at the initial levels of knowledge and understanding; in the affective area, the level of receptivity and in the psychomotor, the perception are more frequently present. The calculation of the GPI shows that among the average training priorities found, the items that include cognitive skills have a higher percentage, followed, respectively, by affective skills and psychomotor skills. This analysis of the domains and learning outcomes would subsidize the planning of an educational action adequate to the defined instructional objectives, i.e., the very competencies described in the instrument, indicating that training with a focus on cognitive skills, or on knowledge primarily technical, would be the most adequate. In this training model, there is the figure of an instructor who transmits information, concepts, methods and technical procedure, so that the student gets the theoreticalpractical content to be trained and performs activities such as simulations and field work (Meneses et al., 2010).

On the other hand, an affective training, seeking to develop behavioral skills and related to the posture of the professional in the performance with the patient, would attend and benefit other competencies that are intrinsically linked to the emotional and affective area, including in this spectrum values, attitudes, appreciations, interests, dispositions and emotional tendencies of the participants of the educational action. In this sense, with the relevant instructional procedures (e.g., simulations, group dynamics, debates, behavioral modeling), different from those eminently cognitive and traditionally applied, skills would be developed that confront those related to customs and postures shaped by ideologies and socio-cultural context during the entire previous process of personal and professional development of the individual for example, receptivity and respect in welcoming the individual in the assistance, showing tolerance to differences encountered in the work environment, paying attention to 
the individual's speech during the welcome, considering and respecting the person's placements.

This study aimed at building and validating, theoretically and statistically, a TNA instrument for health professionals related to humanized care for LGBT+ individuals in the Brazilian context. It can be affirmed that such purpose was achieved, having been obtained an instrument with evidence of validity and reliability.

The instrument can be used as a tool to measure training needs and identify competence gaps in LGBT + user care for health professionals. Since the national literature does not make available any instrument of this type, this unprecedented measure makes possible the proposal of educational actions compatible with the priority indices raised in the diagnosis. Based on this, managers in health contexts will be able to use the tool to apply it to their team's professionals to verify training needs and, depending on the results obtained, direct the training to professionals with competence gaps, in addition to opting for adequate training according to the nature of the required skills, producing positive and effective reflexes in the assistance to the health system user. Besides being used to evaluate the importance and mastery of each KSA in self-evaluation (health professionals, as in the case of this study), it can also be applied in hetero-evaluation (management and patients), in order to complement the self-reported information about the competence gaps of health professionals, which can be confirmed (or not) by superiors and users of services.

To fill the gaps identified, relevant interventions should be programmed according to the nature of the competencies to be developed, aiming at obtaining effective results in the application and transfer of skills to the work. It is important to emphasize the need to develop complex skills, such as interpersonal, in the health area, and the use of more than one sense in educational instructions or actions, not only cognition, but also affection and emotion. Therefore, training for health professionals should consider externalities, which include macro intervening variables such as culture, beliefs and values of individuals. Therefore, such interventions (trainings) should be performed in the long term, since changes in health professionals' skills and attitudes in attending LGBT+ individuals involve other variables (much more complex than those of the knowledge level), not only of the cognitive level, for the transference to occur in practice.

For this reason, first of all, the necessary competencies to attend this public and the gaps should be raised by defining training priorities (GPI calculation), and then analyzing other influential variables that may interfere with the success of the educational actions implemented and also in the work context, such as prejudice. The change in the training of these professionals will occur in the long term, as it depends on changes in society in general. Undergraduate curricula and other training will need to consider the training of eminently cognitive content, coupled with social skills training (intra and interpersonal) and affective content for successful performance in the labor market. Permanent health education depends on interventions, in educational terms, diversified in type and nature, to achieve the development of cognitive and technical skills, but also those of the affective domain, such as those of attitudinal and behavioral nature present in the instrument.

Despite the contributions of the study, a limitation refers to certain homogeneity of the sample in terms of professional categories, the area of psychology being the most frequent. It is suggested that the instrument be applied to a more heterogeneous sample of health professionals, to confirm or rectify the results found. Another limitation is related to the fact that the instrument prioritizes the cognitive domain over the affective one. This is at the basis of the prejudice of professionals towards the LGBT+ public, inducing them to practice discriminatory behaviors in health contexts. An alternative would be, concomitantly to the application of the TNA measure, to directly assess the levels of prejudice of professionals, complementing the information for the training proposal. Another point to be considered is the greater participation in the validation process of health professionals who have declared themselves as heterosexual. In this sense, it is recommended that the instrument be reviewed by health professionals and also by health system users who do not identify themselves as heterosexual, providing a holistic and more appropriate look at the needs of the target public, as to how to provide and receive assistance from health professionals, according to the viewpoint of the users of the services themselves.

As for the sample of professionals who made up the face-to-face data collection, the restriction on the number of health professionals participating points to the difficulty in talking about the issue of diversity or exposing its gaps in the performance directed at the LGBT+ public, since several of them refused to respond to the survey when they had clarity of their objectives. By identifying the discomfort of some professionals in collaborating due to the LGBT+ issue, the title of the survey was changed to "health professionals' assistance to sexual minorities", a fact that seems to have provided greater acceptance by professionals in participating in the survey.

As a research agenda, it is proposed that the tool be applied in various samples and contexts to carry out diagnoses on the skills gaps in health care for the LGBT+ public, as well as that, interventions in terms of education may be proposed from the TNA.

\section{Referências}

Alpert, A. B., Cichoskikelly, E. M., \& Fox, A. D. (2017). What lesbian, gay, bisexual, transgender, queer, and intersex patients say doctors should know and do: A qualitative study. Journal of Homosexuality, 64(10), 1368-1389. doi:10.1080/00918369.2017.1321376 
Beagan, B., Fredericks, E., \& Bryson, M. (2015). Family physician perceptions of working with LGBTQ patients: Physician training needs. Canadian Medical Education Journal, 6(1), e14-e22. Retrieved from https://www.ncbi. nlm.nih.gov/pmc/articles/PMC4563618/pdf/cmej0614.pdf

Bidell, M. P. (2017). The Lesbian, Gay, Bisexual, and Transgender Development of Clinical Skills Scale (LGBT-DOCSS): Establishing a new interdisciplinary self-assessment for health providers. Journal of Homosexuality, 64(10), 1432-1460. doi:10.1080/009183 69.2017 .1321389

Borges-Andrade, J. E., \& Lima, S. V. L. (1983). Avaliação de necessidadesdetreinamento:Ummétododeanálisedepapel ocupacional [Training needs assessment: An occupational role analysis method]. Tecnologia Educacional, 12(54), 6-22. Retrieved from http://www.sidalc.net/ cgi-bin/wxis.exe/? Isis Script=ACERVO.xis \& method $=$ post $\&$ formato $=2 \&$ cantidad $=1 \&$ expresion $=$ $\mathrm{mfn}=007219$

Carabez, R., Pellegrini, M., Mankovitz, A., Eliason, M., Ciano, M., \& Scott, M. (2015). "Never in all my years. . .": Nurses' education about LGBT health. Journal of Professional Nursing, 31(4),323-329. doi:10.1016/j.profnurs.2015.01.003

Carvalho, L. S., \& Philippi, M. M. (2013). Percepção de lésbicas, gays e bissexuais em relação aos serviços de saúde [Lesbians, gays and bissexuals' perception of health services]. Universitas: Ciências da Saúde, 11(2), 83-92. doi:10.5102/ucs.v11i2.1837

Costa, A., Rosa Filho, H., Pase, P. F., Fontanari, A. M. V., Catelan, R. F., Mueller, A., ... Koller, S. H. (2018). Healthcare needs of and access barriers for Brazilian transgender and gender diverse people. Journal of Immigrant and Minority Health, 20(1), 115-123. doi:10.1007/s10903-016-0527-7

Dowshen, N., Meadows, R., Byrnes, M., Hawkins, L., Eder, J., \& Noonan, K. (2016). Policy perspective: Ensuring comprehensive care and support for gender nonconforming children and adolescents. Transgender Health, 1(1), 75-85. doi:10.1089/trgh.2016.0002

Dubin, S. N., Nolan, I. T., Streed C. G., Jr., Greene, R. E., Radix, A. E., \& Morrison, S. D. (2018). Transgender health care: Improving medical students' and residents' training and awareness. Advances in Medical Education and Practice, 9, 377-391. doi:10.2147/AMEP.S147183

Field, A. (2009). Discovering statistics using IBM SPSS statistics (3rd ed.). London, United Kingdom: Sage.

Hair, J. F., Jr., Black, W. C., Babin, B. J., Anderson, R. E., \& Tatham, R. L. (2009). Análise multivariada de dados [Multivariate data analysis] (A. S. Sant'Anna, Trans., 6th ed.). Porto Alegre, RS: Bookman.
Meneses, P. P. M., \& Zerbini, T. (2009). Levantamento de necessidades de treinamento: Reflexões atuais [Needs training survey: Current reflections]. Análise, 20(2), 5064. Retrived from http://www.anpad.org.br/diversos/ down_zips/9/enanpad2005-gpra-1621.pdf

Meneses, P. P. M., Zerbini, T., \& Silva, G. A. (2010). Manual de treinamento organizacional [Organizational training manual]. Porto Alegre, RS: Artmed.

Ministério da Saúde. Secretaria de Gestão Estratégica e Participativa. Departamento de Apoio à Gestão Participativa. (2013). Política Nacional de Saúde Integral de Lésbicas, Gays, Bissexuais, Travestis e Transexuais [National Policy on Integral Health of Lesbians, Gays, Bisexuals, Transvestites and Transsexuals]. Brasília, DF: Autor. Retrieved from http://bvsms.saude.gov.br/bvs/ publicacoes/politica_nacional_saude_lesbicas_gays.pdf

Moe, J. L., \& Sparkman, N. M. (2015). Assessing service providers at LGBTQ-Affirming community agencies on their perceptions of training needs and barriers to service. Journal of Gay \& Lesbian Social Services, 27(3), 350-370. doi:10.1080/10538720.2015.1051687

Müller, A. (2013). Teaching lesbian, gay, bisexual and transgender health in a South African health sciences faculty: Addressing the gap. BMC Medical Education, 13(1), 174. doi:10.1186/1472-6920-13-174

Paradiso, C., \& Lally, R. M. (2018). Nurse practitioner knowledge, attitudes, and beliefs when caring for transgender people. Transgender Health, 3(1), 47-56. doi:10.1089/trgh.2017.0048

Pasquali, L. (2010). Instrumentação psicológica: Fundamentos e práticas [Psychological instrumentation: Fundamentals and practices]. Porto Alegre, RS: Artmed.

Pasquali, L. (2005). Análise fatorial para pesquisadores [Factorial analysis for researchers]. Brasília, DF: LabPAM.

Poteat, T., Park, C., Solares, D., Williams, J. K., Wolf, R. C., Metheny, N., ... Toiv, N. (2017). Changing hearts and minds: Results from a multi-country gender and sexual diversity training. PLoS One, 12(9), e0184484. doi:10.1371/journal.pone.0184484

Tabachnick, B. G., \& Fidell, L. S. (2013). Using multivariate statistics (6th ed.). Boston, MA: Pearson Education.

Talan, A. J., Drake, C. B., Glick, J. L., Claiborn, C. S., \& Seal, D. (2017). Sexual and gender minority health curricula and institutional support services at U.S. schools of public health. Journal of Homosexuality, 64(10), 1350 1367. do i:10.1080/00918369.2017.1321365 
Zelin, N. S., Hastings, C., Beaulieu-Jones, B. R., Scott, C., Rodriguez-Villa, A., Duarte, C., ... Adami, A. J. (2018). Sexual and gender minority health in medical curricula in New England: A pilot study of medical student comfort, competence and perception of curricula. Medical Education Online, 23(1), 1461513. doi:10.1080/10872981.2018.1461513

Willian Roger Dullius holds a Master's Degree in Psychology from IMED, Passo Fundo-RS, Brazil.

Lara Barros Martins is a Professor of the Health School at IMED, Passo Fundo-RS, Brazil.

\section{Authors' Contribution:}

All authors made substantial contributions to the conception and design of this study, to data analysis and interpretation, and to the manuscript revision and approval of the final version. All the authors assume public responsibility for content of the manuscript.

Received: Jun. 10, 2019

1st Revision: Sep. 17, 2019

2nd Revision: Nov. 15, 2019

Approved: Dec. 04, 2019
How to cite this article:

Dullius, W. R., \& Martins, L. B. (2020). Training needs measure for health care of the LGBT+ public. Paidéia (Ribeirão Preto), 30, e3034.doi:https://doi.org/10.1590/1982-4327e3034 